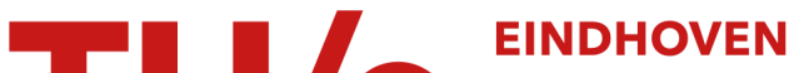 \\ UNIVERSITY OF \\ TECHNOLOGY
}

\section{Liquid phase epitaxial growth of lithium ferrite-aluminate films}

Citation for published version (APA):

Straten, van der, P. J. M., \& Metselaar, R. (1980). Liquid phase epitaxial growth of lithium ferrite-aluminate films. Journal of Crystal Growth, 48(1), 114-120. https://doi.org/10.1016/0022-0248(80)90200-6

DOI:

10.1016/0022-0248(80)90200-6

Document status and date:

Published: 01/01/1980

\section{Document Version:}

Publisher's PDF, also known as Version of Record (includes final page, issue and volume numbers)

\section{Please check the document version of this publication:}

- A submitted manuscript is the version of the article upon submission and before peer-review. There can be important differences between the submitted version and the official published version of record. People interested in the research are advised to contact the author for the final version of the publication, or visit the $\mathrm{DOI}$ to the publisher's website.

- The final author version and the galley proof are versions of the publication after peer review.

- The final published version features the final layout of the paper including the volume, issue and page numbers.

Link to publication

\section{General rights}

Copyright and moral rights for the publications made accessible in the public portal are retained by the authors and/or other copyright owners and it is a condition of accessing publications that users recognise and abide by the legal requirements associated with these rights.

- Users may download and print one copy of any publication from the public portal for the purpose of private study or research.

- You may not further distribute the material or use it for any profit-making activity or commercial gain

- You may freely distribute the URL identifying the publication in the public portal.

If the publication is distributed under the terms of Article 25fa of the Dutch Copyright Act, indicated by the "Taverne" license above, please follow below link for the End User Agreement:

www.tue.nl/taverne

Take down policy

If you believe that this document breaches copyright please contact us at:

openaccess@tue.nl

providing details and we will investigate your claim. 
Journal of Crystal Growth 48 (1980) 114-120

(c) North-Holland Publishing Company

\title{
LIQUID PHASE EPITAXIAL GROWTH OF LITHIUM FERRITE-ALUMINATE FILMS
}

\author{
P.J.M. VAN DER STRATEN and R. METSELAAR \\ Laboratory of Physical Chemistry, University of Technology, Eindhoven, The Netherlands
}

Received 7 May 1979; manuscript received in final form 9 August 1979

Results are presented concerning the growth of $\mathrm{Li}_{0.5} \mathrm{Fe}_{2.5-x} \mathrm{Al}_{x} \mathrm{O}_{4}(0 \leqslant x \leqslant 0.68)$ single crystals and single crystalline films. The films were grown by means of liquid phase epitaxy, LPE, from dilute $\mathrm{PbO}-\mathrm{B}_{2} \mathrm{O}_{3}$ fluxes on (111)- $\mathrm{MgO}$ or (111)- $\mathrm{Zn}(\mathrm{Ga}$, $\mathrm{Al}_{2} \mathrm{O}_{4}$ substrates. It is shown that at temperatures above about $1000^{\circ} \mathrm{C}$ thin lithium ferrite films grown on $\mathrm{MgO}$ are contaminated seriously by the substrate due to interdiffusion.

\section{Introduction}

Single crystals of lithium ferrite-aluminate may find applications in ferrite superhigh-frequency technology [1]. Pure lithium ferrite has properties (such as high magnetization and high Curie temperature) which would make it superior to YIG as a microwave material. While YIG has become an important microwave material lithium ferrite has not. Problems concerning growth and fabrication of single crystals have resulted in losses much higher than expected [2].

We have studied the growth of lithium ferritealuminate films as a part of our research program concerning the LPE growth and characterization of spinel ferrite films. Our interest is mainly aimed on films with an easy axis of magnetization perpendicular to the plane of the film. Therefore a uniaxial anisotropy (stress- and/or growth-induced) must be present, preferably exceeding the demagnetization energy $2 \pi M_{S}^{2}$ [3]. The existence of a compensation point in the $4 \pi M_{\mathrm{s}}$-composition diagram of $\mathrm{Li}_{0.5} \mathrm{Fe}_{2.5-x} \mathrm{Al}_{x} \mathrm{O}_{4}$ for $x \sim 0.7$ is very helpful in this regard.

\section{The growth of lithium ferrite films}

Rybal'skaya et al. [4] have determined the solubility of lithium ferrite in a $\mathrm{PbO}-0.52 \mathrm{~B}_{2} \mathrm{O}_{3}$ solvent using a $\mathrm{Li}_{2} \mathrm{O}: \mathrm{Fe}_{2} \mathrm{O}_{3}$ molar ratio of $2: 3$ (fig. 1). Melt compositions for the flux growth of lithium fer- rite are known from literature $[2,4-8]$. The reported $\mathrm{Li}_{2} \mathrm{O}: \mathrm{Fe}_{2} \mathrm{O}_{3}$ ratios are only slightly different from the ratio applied by ref. [4]. For LPE growth normally very dilute melts are used with relatively low

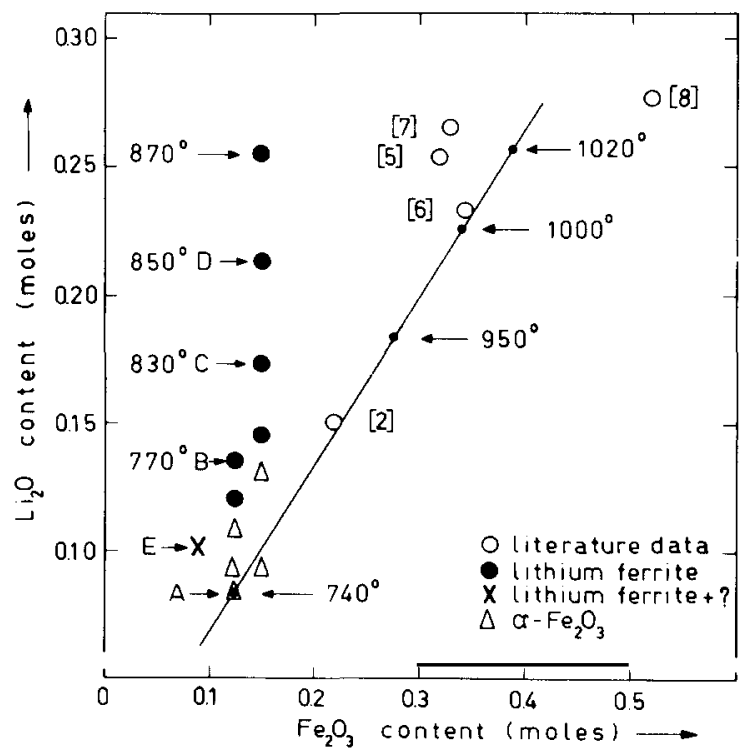

Fig. 1. $\mathrm{Li}_{2} \mathrm{O}$ and $\mathrm{Fe}_{2} \mathrm{O}_{3}$ contents in a $\mathrm{PbO}-0.52 \mathrm{~B}_{2} \mathrm{O}_{3}$ flux. The solubility of lithium ferrite [1] is given by the straight line together with some saturation temperatures $(\bullet)$ in ${ }^{\circ} \mathrm{C}$. The symbols are representing literature data concerning the flux growth of lithium ferrite and the various compositions used in this study. Approximated saturation temperatures are given. For the letters $\mathrm{A}-\mathrm{E}$ consult the text. 
saturation temperatures. The melt composition given by Rybal'skaya [4] with a saturation temperature of $740^{\circ} \mathrm{C}$ seemed a good choice in this respect.

The melt was prepared from reagent grade $\mathrm{Li}_{2} \mathrm{CO}_{3}$, $\mathrm{Fe}_{2} \mathrm{O}_{3}, \mathrm{~B}_{2} \mathrm{O}_{3}$ and $\mathrm{Fe}_{2} \mathrm{O}_{3}$. The components were melted in a $75 \mathrm{~cm}^{3}$ platinum crucible, which was placed afterwards in an LPE growth furnace as described before [9]. When the melt was cooled to about $700^{\circ} \mathrm{C}$, after stirring at elevated temperatures, crystals were observed, floating on the surface of the melt. Instead of lithium ferrite these crystals appeared to be $\alpha-\mathrm{Fe}_{2} \mathrm{O}_{3}$ platelets with large (00.1) facets. Dimensions up to $2 \mathrm{~cm}$ with a thickness of 0.5 min could be obtained. This melt composition (A) seems to be very suitable for the growth of $\mathrm{Fe}_{2} \mathrm{O}_{3}$ crystals but not for lithium ferrite.

We have therefore studied a number of melts with different $\mathrm{Li}_{2} \mathrm{O}: \mathrm{Fe}_{2} \mathrm{O}_{3}$ ratios as indicated in fig. 1 . For melt compositions $\mathrm{PbO}-0.52 \mathrm{~B}_{2} \mathrm{O}_{3}-x\left(2 \mathrm{Li}_{2} \mathrm{O}-\right.$ $3 \mathrm{Fe}_{2} \mathrm{O}_{3}$ ) lithium ferrite crystallizes from these melts when $x \gtrsim 0.06$ and $\alpha-\mathrm{Fe}_{2} \mathrm{O}_{3}$ is produced when $x \leqslant$ 0.06 . Lithium ferrite can also be obtained from melts with $x \leqslant 0.06$ when the $\mathrm{Li}_{2} \mathrm{O}$ content of the melt is increased. When too low $\mathrm{Fe}_{2} \mathrm{O}_{3}$ concentrations are used (melt E) besides lithium ferrite another, so far not identified phase is obtained, which crystallizes as light green-coloured needles.

From melts B, C and D LPE growth was performed according to standard LPE procedures described previously [9] on syton polished, vertically dipped (111)-MgO substrates. Due to a small misorientation of the substrates small terraces can be observed. From the distance between the steps and the step height the angle between the terrace and the substrate was determined as $0.44^{\circ}$. This is in good agreement with the misorientation $\left(0.4^{\circ}\right)$ of the substrate surface compared with the crystallographic (111)plane, which was determined by means of an X-ray texture goniometer. The lattice constants of the lithium ferrite films were determined by X-ray diffractometry by measuring the Bragg angle from planes parallel to (111) using the substrate as internal standard. The obtained value of $8.329 \pm 0.002 \AA$ is very close to the value reported in literature: 8.334 [10]. The film thickness was determined by grinding a spherical hole in the film [9]. With melt $\mathrm{C}$ for instance and using a dipping time of $5 \mathrm{~min}$ a growth rate of $0.7 \mu \mathrm{m} / \mathrm{min}$ was obtained at $790^{\circ} \mathrm{C}$ and 0.1 $\mu \mathrm{m} / \mathrm{min}$ at $820^{\circ} \mathrm{C}$. Above $830^{\circ} \mathrm{C}$ no film growth could be observed anymore. Our results deviate from the results obtained by Glass and Liaw [2] in two respects: Firstly only $\{111\}$-spinel diffraction peaks were observed. The additional diffraction peaks reported by the above-mentioned authors might be attributed to $\alpha \cdot \mathrm{Fe}_{2} \mathrm{O}_{3}$ as a second phase, because their melt composition is very close to compositions at which $\alpha-\mathrm{Fe}_{2} \mathrm{O}_{3}$ precipitation can take place. Secondly our melt is not suffering from unstability and controlled growth can take place even for supersaturations as high as $40^{\circ} \mathrm{C}$.

\section{The growth of lithium ferrite-aluminate films}

Lithium ferrite and lithium aluminate are completely miscible at temperatures above $1200^{\circ} \mathrm{C}$ [10]. Below this temperature there is a broad miscibility gap. At $900^{\circ} \mathrm{C} \mathrm{Li}{ }_{0.5} \mathrm{Fe}_{1.95} \mathrm{Al}_{0.55} \mathrm{O}_{4}$ is in equilibrium with $\mathrm{Li}_{0.5} \mathrm{Fe}_{0.55} \mathrm{Al}_{1.95} \mathrm{O}_{4}$. Due to this miscibility gap problems can be expected if $\mathrm{Li}_{0.5} \mathrm{Fe}_{2.5-x} \mathrm{Al}_{x} \mathrm{O}_{4}$ with $0.55<x<1.95$ must be grown.

For the growth of lithium ferrite-aluminate no melt compositions could be found in literature although in two papers the growth of single crystals is reported. However, there is a discrepancy between the reported $\mathrm{Al}$ contents and lattice constants. The relation between composition $(0 \leqslant x \leqslant 0.33)$ and lattice constant reported by Petrakovskii et al. [1] is a straight line perfectly fitting the Vegard relationship between lithium ferrite and lithium aluminate. From the data of Schulkes and Blasse [11] and from the data of Strickler and Roy [10], however, it is known that a strong positive deviation from the Vegard relation is present in this spinel system. When the data of Petrakovskii et al. are extrapolated to $x=0.5$ a lattice constant of $8.245 \AA$ would result. Yakovlev et al. [12] report the growth of single crystals with $0 \leqslant x \leqslant 0.5$. A lattice constant of $8.288 \AA$ is given for $x=0.5$; in excellent agreement with the results of Schulkes and Blasse.

The growth of single crystals and LPE films of lithium ferrite-aluminate was accomplished. from melts $\mathrm{B}$ and $\mathrm{D}$ after additions of $\mathrm{Al}_{2} \mathrm{O}_{3}$ to these melts. (See table 1.) The films were grown by vertically dipping for $10 \mathrm{~min}$ using supersaturations of approximately $20-40^{\circ} \mathrm{C}$. With increasing $\mathrm{Al}_{2} \mathrm{O}_{3}$ content of 
Table 1

Melt compositions (moles), growth temperatures $T_{\mathrm{g}}\left({ }^{\circ} \mathrm{C}\right)$ and growth rates $r(\mu \mathrm{m} / \mathrm{min})$ for melts B and D

\begin{tabular}{|c|c|c|c|c|c|}
\hline \multicolumn{3}{|c|}{$\begin{array}{l}\text { Melt B: } \\
1 \mathrm{PbO}-0.52 \mathrm{~B}_{2} \mathrm{O}_{3}-0.135 \mathrm{Li}_{2} \mathrm{O}-0.125 \mathrm{Fe}_{2} \mathrm{O}_{3}-y \mathrm{Al}_{2} \mathrm{O}_{3}\end{array}$} & \multicolumn{3}{|c|}{$\begin{array}{l}\text { Melt } \mathrm{D} \text { : } \\
1 \mathrm{PbO}-0.52 \mathrm{~B}_{2} \mathrm{O}_{3}-0.213 \mathrm{Li}_{2} \mathrm{O}-0.152 \mathrm{Fe}_{2} \mathrm{O}_{3}-z \mathrm{Al}_{2} \mathrm{O}_{3}\end{array}$} \\
\hline$y$ (moles) & $\left.T_{\mathrm{g}}{ }^{\circ} \mathrm{C}\right)$ & $r(\mu \mathrm{m} / \mathrm{min})$ & $z$ (moles) & $T_{\mathrm{g}}(\mathrm{C})$ & $r(\mu \mathrm{m} / \mathrm{min})$ \\
\hline 0.039 & 770 & 0.53 & 0.030 & 840 & 0.60 \\
\hline 0.069 & 790 & 0.42 & 0.049 & 855 & 0.44 \\
\hline 0.098 & 805 & 0.40 & 0.098 & 858 & 0.62 \\
\hline 0.147 & 821 & 0.41 & 0.147 & 870 & 0.49 \\
\hline \multirow[t]{2}{*}{0.177} & 829 & 0.48 & 0.162 & 878 & 0.64 \\
\hline & & & 0.187 & 890 & 0.47 \\
\hline
\end{tabular}

the melt the saturation temperature of the melt increases. Therefore the growth temperature has to be increased as well in order to prevent spontaneous nucleation in the melt. Melt compositions, corresponding growth temperatures $\left(T_{\mathrm{g}}\right)$ and growth rates $(r)$ are listed in table 1 . The film compositions were determined by electron microprobe analyses. The concentrations were calculated with the aid of a computing program using the measured intensities of pure $\mathrm{Fe}, \mathrm{Al}$ and $\mathrm{Pb}$ as standards. Because lithium and oxygen could not be measured directly, we have put $(\mathrm{Li}+\mathrm{O})$ at 4.5 atoms per formula unit. The results were checked by using sintered $\mathrm{Li}_{0.5} \mathrm{Fe}_{2.5-x} \mathrm{Al}_{x} \mathrm{O}_{4}$ internal standards with $x=0,0.25,0.50$ and 0.75 . An

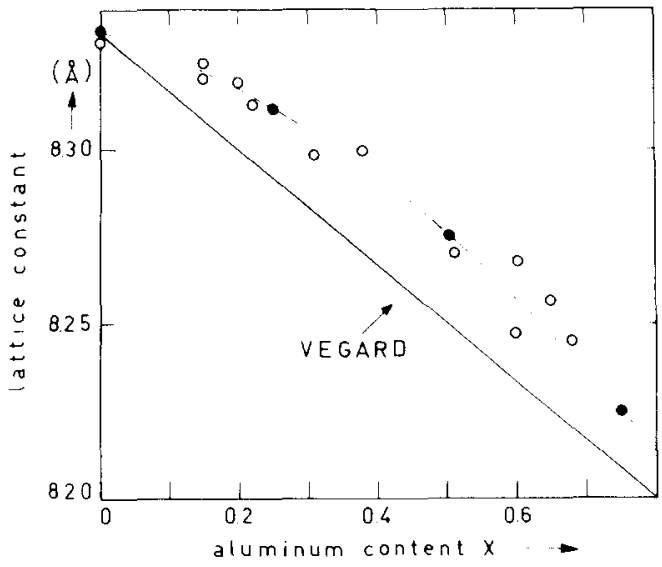

Fig. 2. The lattice constants of $\mathrm{Li}_{0.5} \mathrm{Fe}_{2.5-x} \mathrm{Al}_{x} \mathrm{O}_{4}$ films (o) grown on (111)-MgO substrates and of sintered standards $(\bullet)$ versus the aluminum content $x$. Straight line represents Vegard relationship. accuracy for $\mathrm{Fe}$ and $\mathrm{Al}$ of \pm 0.03 atoms per formula unit was obtained. The $\mathrm{Pb}$ content of our films was lower than 0.01 atoms per formula unit.

In fig. 2 the lattice constants of the films are plotted versus the Al-content. In agreement with literature a positive deviation from the Vegard law is observed and good agreement is obtained with the values of the sintered internal standards.

The segregation coefficient for $\mathrm{Al}$, defined as the mole ratio

$k_{\mathrm{Al}}=[\mathrm{Al} /(\mathrm{Fe}+\mathrm{Al})]_{\text {film }} /[\mathrm{A} 1 /(\mathrm{Fe}+\mathrm{Al})]_{\text {melt }}$

is plotted in fig. 3 versus the growth temperature. A linear relationship is obtained: $k_{\mathrm{Al}}$ increases with increasing temperature. An increase of the $\mathrm{Li}_{2} \mathrm{O}$ content causes a decrease of $k_{\mathrm{A} 1}$. It has to be noted that

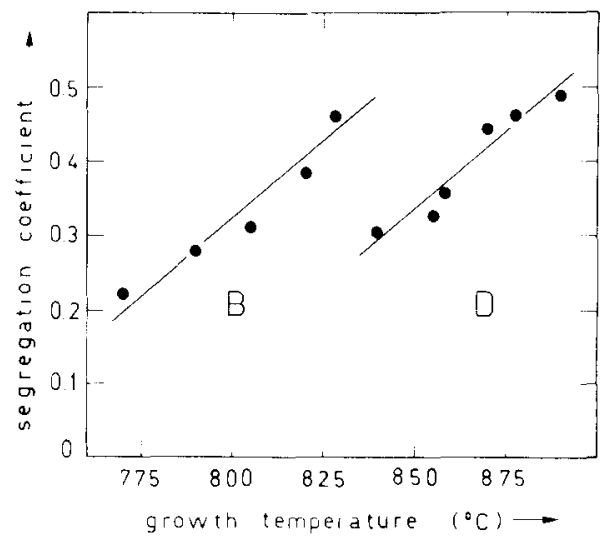

Fig. 3. The segregation coefficient for aluminum versus the growth temperature. $\mathrm{B}$ and $\mathrm{D}$ indicate two melts with different $\mathrm{Li}_{2} \mathrm{O}: \mathrm{Fe}_{2} \mathrm{O}_{3}$ ratios (fig. 1). 


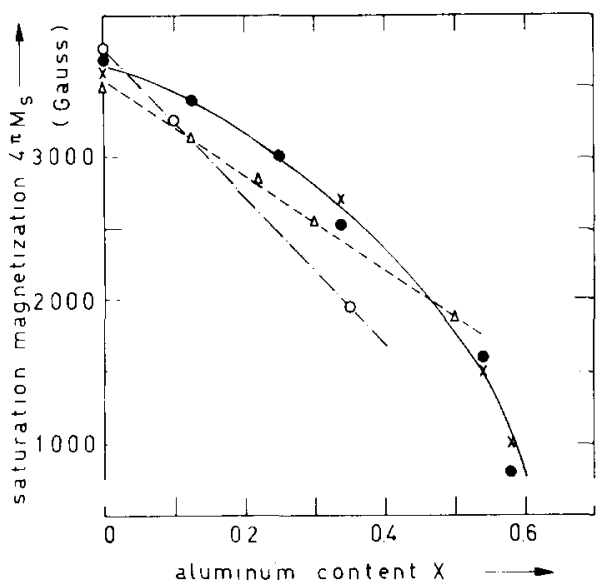

Fig. 4. The saturation magnetization $4 \pi M_{\mathrm{S}}$ at room temperature versus the aluminum content $x$ in $\mathrm{Li}_{0.5} \mathrm{Fe}_{2.5}-x \mathrm{Al}_{x} \mathrm{O}_{4}$; $(\bullet)$ LPE films, $(X)$ single crystals, $(O)$ Dionne $[18],(\Delta)$ Yakovlev et al. [12].

the segregation coefficients are calculated for films grown with slightly different growth rates and grown from melts with different $\mathrm{Al}_{2} \mathrm{O}_{3}$ concentrations. Films with $x$ up to 0.68 could be grown at $900^{\circ} \mathrm{C}$. Attempts to increase the $\mathrm{Al}$ content by further additions of $\mathrm{Al}_{2} \mathrm{O}_{3}$ to the melt were unsuccessful. A second spinel phase with a lattice constant of $8.03 \AA$ $(x \sim 1.95)$ was observed; in agreement with the composition data of the miscibility gap $(0.55<x<1.95)$ at $900^{\circ} \mathrm{C}$. Obviously under conditions of epitaxial growth a little more $\mathrm{Al}(x=0.68)$ can be substituted than expected $(x=0.55)$.

The saturation magnetization of crystals and films is determined using a Faraday balance: the product of magnetization and volume could be determined directly. After determination of the volume of the layer or crystal the saturation magnetization results with an accuracy of 5-10\%. In fig. 4 the magnetizatization is plotted versus the aluminum content of film and crystals.

\section{Interdiffusion between film and substrate}

In our attempts to grow films with $x>0.68$, more concentrated melts with higher saturation temperatures were used: At higher temperatures the miscibility gap is smaller and the segregation coefficient for

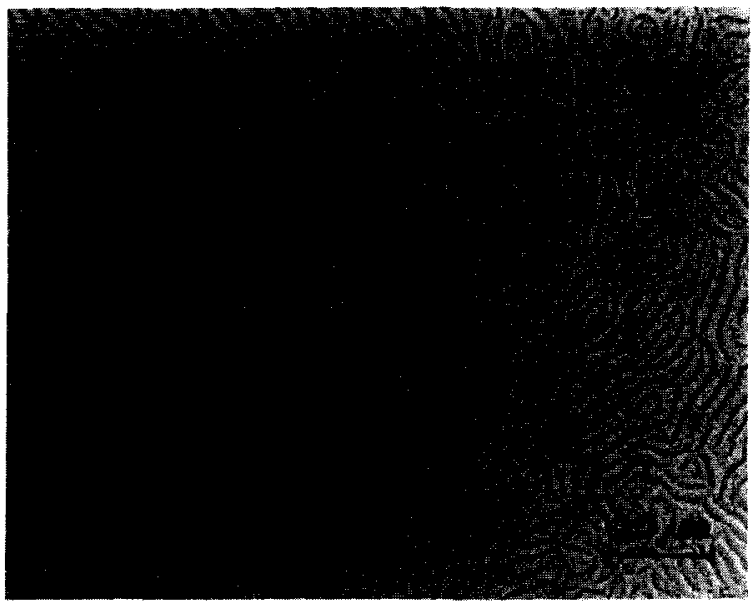

Fig. 5. Bitter pattern observed on a $\mathrm{Li}_{0.5}(\mathrm{Fe}, \mathrm{Al})_{2.5} \mathrm{O}_{4}$ film grown at $1050^{\circ} \mathrm{C}$ on a (111)-MgO substrate.

$\mathrm{Al}$ is larger. We have used temperatures up to $1050^{\circ} \mathrm{C}$. When an Al-rich second phase was observed the lattice constant of the Fe-rich epitaxial layer was, however, higher than at temperatures of $900^{\circ} \mathrm{C}$. When Bitter fluid was applied to the surface of the film a pattern looking like "broken serpentines" (fig. 5) was observed. This pattern could not be observed on films grown at $900^{\circ} \mathrm{C}$. Microprobe analyses revealed the presence of $\mathrm{Mg}$ in the annealed film. Obviously interdiffusion occurs between film and substrate resulting in a solid solution between $\mathrm{MgFe}_{2} \mathrm{O}_{4}$ and $\mathrm{Li}_{0.5}(\mathrm{Fe}, \mathrm{Al})_{2.5} \mathrm{O}_{4}$. This interdiffusion causes an increase in the lattice constant of the film. The observed Bitter pattern may be due to some stress introduced by the diffusion proces.

In order to check this, we have annealed lithium ferrite films grown at $900^{\circ} \mathrm{C}$ on $\mathrm{MgO}$ substrates. The lattice constants were measured as function of time for a $3 \mu \mathrm{m}$ and for a $22 \mu \mathrm{m}$ film after annealing at 1000,1100 and $1200^{\circ} \mathrm{C}$ in oxygen. Whereas the diffraction angle of the $\mathrm{MgO}$ substrate remained constant, the diffraction peak of the film, without much broadening, moved towards the substrate peak, indicating an increase of the film lattice constant. Fig. 6 shows the results for the $22 \mu \mathrm{m}$ film. The rapid increase of the lattice constant can be attributed to interdiffusion of ions bwteen film and substrate, i.e. the formation of $(\mathrm{Mg}, \mathrm{Li}, \mathrm{Fe})_{3} \mathrm{O}_{4}$. 


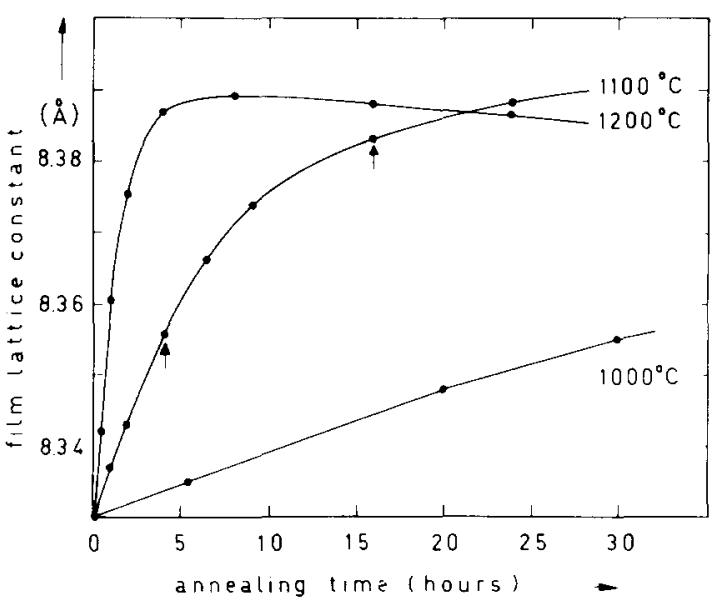

Fig. 6. The lattice constant of "lithium ferrite" films versus the annealing time for a film with a thickness of $22 \mu \mathrm{m}$, annealed at 1000,1100 and $1200^{\circ} \mathrm{C}$. The arrows refer to fig. 7 .

To verify this assumption microprobe analyses were performed. After annealing at $1100^{\circ} \mathrm{C}$ for 4 and $16 \mathrm{~h}$ the film was ground and polished perpendicular to the film surface. The iron and magnesium concentrations were calculated from the measured X-ray intensities, the lithium content was calculated by difference, assuming four oxygen atoms per formula unit. The results are presented in fig. 7. The figure clearly shows the rapid diffusion of $\mathrm{Mg}$ ions into the film and counterdiffusion of $\mathrm{Fe}$ and $\mathrm{Li}$ into the sub. strate. Apart from $\mathrm{Li}$ diffusion into the substrate the possibility of evaporation of $\mathrm{Li}_{2} \mathrm{O}$ is present. This would result in the formation of $\gamma-\mathrm{Fe}_{2} \mathrm{O}_{3}$ in the film, which may precipitate as $\alpha-\mathrm{Fe}_{2} \mathrm{O}_{3}$ [13]. Indeed, after annealing at high temperatures we have observed a second phase at the film surface (fig. 8). Both from $\mathrm{X}$-ray diffractometry and microprobe analysis the second phase proved to be $\alpha-\mathrm{Fe}_{2} \mathrm{O}_{3}$. The formation of $\gamma-\mathrm{Fe}_{2} \mathrm{O}_{3}\left(a_{0}=8.33 \AA\right)$ in the film could be the cause of the slight decrease of the lattice constant observed at $1200^{\circ} \mathrm{C}$ for annealing times larger than $10 \mathrm{~h}$ as shown in fig. 6 . From our diffusion study it can be concluded that for temperatures above about $1000^{\circ} \mathrm{C}$ severe interdiffusion occurs during the growth of thin lithium ferrite films.

In view of this result serious doubt is felt concerning the composition of "lithium ferrite" films grown by Gambino [14], since these films were grown at

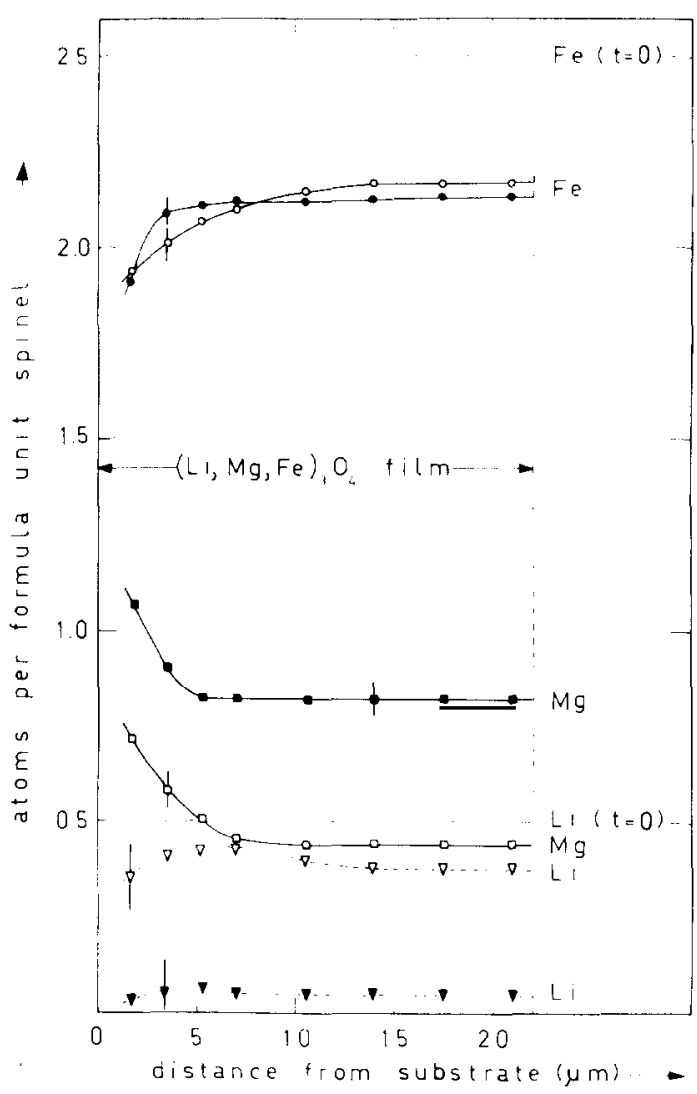

Fig. 7. Concentration profiles in a $22 \mu \mathrm{m}$ "lithium ferrite" film grown on a $\mathrm{MgO}$ substrate at $900^{\circ} \mathrm{C}$ after annealing in oxygen at $1100^{\circ} \mathrm{C}$ for $4 \mathrm{~h}$ (open symbols) and for $16 \mathrm{~h}$ (closed symbols).

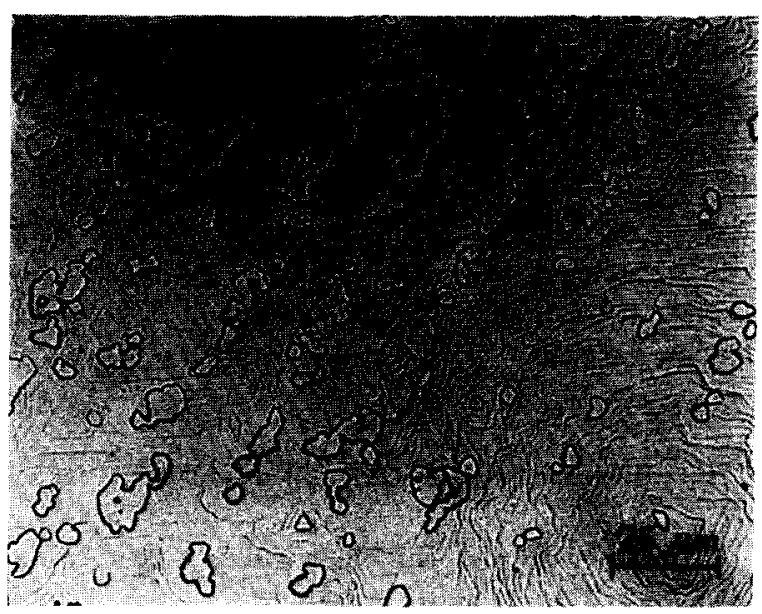

Fig. 8. $\alpha-\mathrm{Fe}_{2} \mathrm{O}_{3}$ precipitates observed on the surface of a "lithium ferrite" film after prolonged annealing at $1200^{\circ} \mathrm{C}$. 
$1150^{\circ} \mathrm{C}$ with a growth rate of about $0.05 \mu \mathrm{m} / \mathrm{min}$. We strongly believe that the various ferrite films grown by Gambino at temperatures ranging from 1100$1250^{\circ} \mathrm{C}$ must be suffering from severe interdiffusion. This is in agreement with his observation that "the lattice constants of the as-grown films were consistently slightly higher than their reported values".

\section{The magnetostriction constants of lithium ferrite- aluminate}

A stress-induced uniaxial anisotropy in thin films results from magnetostriction and misfit. Lithium ferrite undergoes an ionic order-disorder transition [15] at a temperature of about $750^{\circ} \mathrm{C}$. Petrakovskii and Smokotin [16] found that the magnetostriction constants $\lambda_{100}$ and $\lambda_{111}$ are sensitive to the change of ionic ordering. These results were confirmed by Arai and Tsuya [17]; $\lambda_{111}$ ordered state: $3.9 \times 10^{-6}$; $\lambda_{111}$ disordered state: $2.7 \times 10^{-6}$. The magnetostriction constants of $\mathrm{Li}_{0.5} \mathrm{Fe}_{2.5-x} \mathrm{Al}_{x} \mathrm{O}_{4}$ as function of $x$ are reported by Dionne [18] and by Petrakovskii et al. [1], without mentioning the order-disorder dependence. In fig. 9 literature values of $\lambda_{111}$ are plotted versus the Al content $x$.

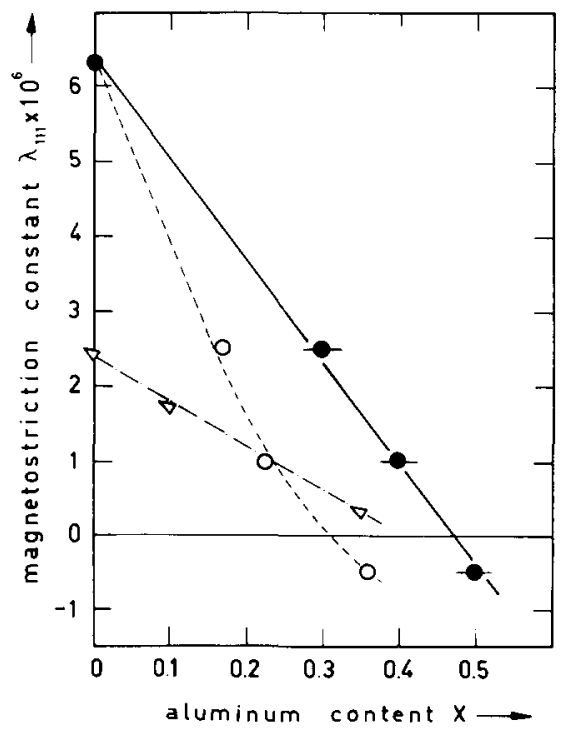

Fig. 9. Magnetostriction constant $\lambda_{111}$ versus the aluminum content $x$ in $\mathrm{Li}_{0.5} \mathrm{Fe}_{2.5}-x \mathrm{Al}_{x} \mathrm{O}_{4} ;(\nabla)$ values from Dionne $[18] ;(0)$ values from Petrakovskii et al. $[1] ;(\bullet)$ corrected values (see text).
We believe that the compositions given by Petrakovskii et al. [1] are wrong: Firstly, the reported linear relationship between lattice constant and composition is not valid in the lithium ferrite-aluminate system; secondly, there is a discrepancy between the data on saturation magnetization at $78 \mathrm{~K}$ by Petrakovskii et al. [1] and Yakovlev [12]. Both data can be brought in agreement with each other if the aluminum contents given by Petrakovskii et al. [1] are increased, keeping the lattice constants unchanged, until they coincide with the relation between aluminum content and lattice constant as shown in fig. 2 . Probably the compositions given by Petrakovskii et al. [1] were not actually determined, but derived from the lattice constant data assuming a linear relationship between lithium ferrite and lithium aluminate; which is reported to be not true in this system. When the corrected compositions are introduced the relation between magnetostriction constants and aluminum content becomes linear (fig. 9). Dionne [18] also found a linear relationship. Still the values presented by Petrakovskii et al. [1] and Dionne [18] differ by about $300 \%$. The order-disorder transformation as well as the method used for the determination of $\lambda$ may be the cause of this difference. For instance the FMR method used by Dionne is very sensitive to stresses present in the sample.

In spite of the uncertainties in the actual values we can conclude that $\lambda_{111}>0$ for $x \leqslant 0.35$. This means that a stress-induced anisotropy in LPE grown lithium ferrite-aluminate films can be generated for these compositions if compressive films $\left(a_{\mathrm{f}}>a_{\mathrm{s}}\right)$ are grown. However, $\mathrm{MgO}$ substrates $\left(2 a_{\mathrm{s}}=8.42 \AA\right)$ are not suitable in this case: The large misfit would result in stress-relief at the growth temperature [19]. On $\mathrm{Zn}(\mathrm{Ga}, \mathrm{Al})_{2} \mathrm{O}_{4}$ substrates [20] with lattice constants of 8.31 and $8.28 \AA$ compressive films can be grown. For $\mathrm{Li}_{0.5} \mathrm{Fe}_{2.5} \mathrm{O}_{4} \quad\left(a_{\mathrm{f}}=8.330 \AA, 2 \pi M_{\mathrm{s}}^{2} \sim 55 \times 10^{4}\right.$ $\mathrm{erg} / \mathrm{cm}^{3}$ ) assuming $\lambda_{111} \sim 4 \times 10^{-6}$, a stress-induced anisotropy $K_{\mathrm{u}}^{\mathrm{s}}\left(a_{\mathrm{s}}=8.31 \AA\right)$ of $\sim 4 \times 10^{4} \mathrm{erg} / \mathrm{cm}^{3}$ can be expected. For $\mathrm{Li}_{0.5} \mathrm{Fe}_{2.2} \mathrm{Al}_{0.3} \mathrm{O}_{4} \quad\left(a_{\mathrm{f}}=8.305 \AA\right.$, $\left.2 \pi M_{\mathrm{s}}^{2} \sim 30 \times 10^{4} \mathrm{erg} / \mathrm{cm}^{3}\right)$ assuming $\lambda_{111} \sim 1 \times 10^{4}$, a $K_{\mathrm{u}}^{\mathrm{s}}\left(a_{\mathrm{s}}=8.28 \AA\right)$ of $\sim 1 \times 10^{4} \mathrm{erg} / \mathrm{cm}^{3}$ can be expected.

Determination of these small anisotropies from torque measurements is quite difficult in films with a high saturation magnetization. With an uncertainty of about $10 \%$ in the $M_{\mathrm{s}}$ values, an uncertainty of 
about $20 \%$ results in the $2 \pi M_{\mathrm{s}}^{2}$ values, while the $K_{\mathrm{u}}^{\mathrm{s}}$ is less than $10 \%$ of the $2 \pi M_{\mathrm{s}}^{2}$ value.

As to be expected, in the composition range $0<$ $x<0.5$ none of the films grown during the study showed any evidence of a uniaxial anisotropy from torque measurements. When Bitter fluid was applied to the surface no serpentine like domain pattern could be observed either, indicating a zero or extremely low uniaxial anisotropy (in the case of $\mathrm{NiFe}_{2-x} \mathrm{Al}_{x} \mathrm{O}_{4}$ films grown on $\mathrm{ZnGa}_{2} \mathrm{O}_{4}$ substrates [3] serpentine like domain patterns could be observed when the $K_{\mathrm{u}}^{\mathrm{s}}$ was about $10 \%$ of the $2 \pi M_{\mathrm{s}}^{2}$ ). In conclusion we may state that we have not succeeded to observe a uniaxial anisotropy in lithium ferritealuminate films.

\section{Conclusions}

We have established compositions of dilute $\mathrm{PbO}-$ $\mathrm{B}_{2} \mathrm{O}_{3}-\mathrm{Li}_{2} \mathrm{O}-\mathrm{Fe}_{2} \mathrm{O}_{3}$ melts from which lithium ferrite can be grown by spontaneous nucleation as well as by LPE methods. Supersaturations as high as $40^{\circ} \mathrm{C}$ can be used. Compositions in this flux system are also very suitable for the growth of $\alpha-\mathrm{Fe}_{2} \mathrm{O}_{3}$.

By adding $\mathrm{Al}_{2} \mathrm{O}_{3}$ to the flux system lithium ferrite-aluminate can be grown. An approximately linear relationship is found between the segregation coefficient $k_{\mathrm{Al}}$ for $\mathrm{Al}$ and the growth temperature. The amount of $\mathrm{Li}_{2} \mathrm{O}$ in the melt has a strong influence on $k_{\mathrm{Al}}$.

Under conditions of epitaxial growth more $\mathrm{Al}$ can be substituted in lithium ferrite than according to the phase diagram.

When high growth temperatures are used interdiffusion between substrate $(\mathrm{MgO})$ and film is observed resulting in an increase of the lattice constant of the film.

Interdiffusion between $\mathrm{MgO}$ and lithium ferrite has been studied by annealing experiments. From this study we can conclude that spinel ferrite films, grown at temperatures higher than about $1000^{\circ} \mathrm{C}$, must be suffering from severe contamination caused by the substrate.
Our search for lithium ferrite--aluminate films exhibiting a uniaxial anisotropy was unsuccesful. No evidence for such an anisotropy could be found, most likely the stress-induced effect was too small to be detectable.

\section{References}

[1] G.A. Petrakovskii, E.M. Smokotin, L.M. Protopopova and K.A. Sablina, Soviet Phys.-Solid State 12 (1970) 135.

[2] H.L. Glas and J.H.W. Liaw, Mater. Res. Bull. 13 (1978) 353.

[3] P.J.M. van der Straten and R. Metselaar, Mater. Res. Bull. 13 (1978) 1143.

[4] E.V. Rybal'skaya, T.G. Petrov and A.G. Titova, Soviet Phys.-Solid State 15 (1971) 958.

[5] P. Hansen, J. Schuldt, B. Hoekstra and J.P.M. Damen, Phys. Status Solidi (a) 30 (1975) 289.

16] J.P. Remeika and R.L. Comstock, J. Appl. Phys. 35 (1964) 3320.

[7] E.G. Spencer, D.A. Lepore and J.W. Nielsen, J. Appl. Phys. 39 (1968) 732.

[8] A.J. Pointon and J.M. Robertson, J. Mater. Sci. 2 (1967) 293.

[9] P.J.M. van der Straten and R. Metselaar, Mater. Res. Bull. 12 (1977) 707.

[10] D.W. Strickler and R. Roy, J. Am. Ceram. Soc. 44 (1961) 225 .

[11] J.A. Schulkes and G. Blasse, J. Phys, Chem. Solids 24 (1963) 1651

[12] Yu.M. Yakovlev, E.V. Rybal'skaya and B.L. Lapovok, Soviet Phys.-Solid State 10 (1969) 2301.

[13] D.H. Ridgley, H. Lessoff and J.D. Childress, J. Am. Ceram. Soc. 53 (1970) 304.

[14] R.J. Gambino, J. Appl. Phys. 38 (1967) 1129.

[15] M. Brunel and F. de Bergevin, Compt. Rend. (Paris) 258 (1964) 5628.

[16] G.A. Petrakovskii and E.M. Smokotin, Soviet Phys.JETP. 26 (1968) 718.

[17] K.I. Arai and N. Tsuya, J. Phys. Soc. Japan 33 (1972) 1581.

[18] G.F. Dionne, J. Appl. Phys. 40 (1969) 4486.

[19| D.C. Miller and R. Caruso, J. Crystal Growth 27 (1974) 274.

[20] P.J.M. van der Straten, R. Metselaar and H.D. Jonker, J. Crystal Growth 43 (1978) 270. 